\begin{tabular}{|l|l|l|}
\hline \multicolumn{2}{|c|}{ PublisherInfo } \\
\hline \hline PublisherName & $:$ & BioMed Central \\
\hline \hline PublisherLocation & $:$ & London \\
\hline \hline PublisherImprintName & $:$ & BioMed Central \\
\hline \hline
\end{tabular}

\title{
Axon guidance gene screen
}

\begin{tabular}{|l|l|l||}
\hline \multicolumn{2}{|c||}{ ArticleInfo } \\
\hline \hline ArticleID & $:$ & 3539 \\
\hline \hline ArticleDOI & $:$ & $10.1186 /$ gb-2000-1-1-reports006 \\
\hline \hline ArticleCitationID & $:$ & reports006 \\
\hline \hline ArticleSequenceNumber & $:$ & 30 \\
\hline \hline ArticleCategory & $:$ & Paper report \\
\hline ArticleFirstPage & $:$ & 1 \\
\hline \hline ArticleLastPage & $:$ & 3 \\
\hline \hline & & RegistrationDate : 1999-11-5 \\
ArticleHistory & $:$ & Received \\
\hline \hline ArticleCopyright & $:$ & BioMed Central Ltd2000 \\
\hline \hline ArticleGrants & $:$ & \\
\hline \hline ArticleContext & $:$ & 130591111 \\
\hline \hline
\end{tabular}




\section{Alan Shirras}

\section{Abstract}

A genetic screen has identified genes controlling axonal dendrite development.

\section{Significance and context}

Dendrites are complex, branching structures that arise from the cell body of neurons and function in signal reception and the computation and storage of information. To ensure that the correct connections are made in a developing nervous system, it is essential that dendrites have the correct branching pattern. In contrast to the increased understanding of the mechanisms of axon outgrowth and guidance, including the identification of several genes regulating this process in Drosophila, little is known about the molecular mechanisms involved in regulating dendrite morphology. This report describes a systematic genetic screen to identify genes regulating dendrite morphology in Drosophila. It uses the GAL4-UAS system, which is based on the interaction of a transcription factor and its response element, to express green fluorescent protein (GFP) in the dorsal sensory neurons of the peripheral nervous system. In late embryos, the dendritic pattern of these cells is sufficiently invariant in wild-type animals to make a screen by visual inspection possible.

\section{Key results}

The GAL4 line 109(2)80 was chosen as it drives GFP expression in dorsal cluster multiple dendrite (md) neurons. Analysis of these cells in wild-type animals using time-lapse photography and confocal microscopy revealed dendrite formation to be a dynamic process with extensive growth and retraction of lateral branches between 15 and 16 hours after egg laying. Mutations in the previously identified genes prospero, encoding a nuclear protein, and $C d c 42$, encoding a GTP-binding protein of the Rho subfamily, cause defects in dendritic outgrowth and secondary branching. To identify new mutations on the second chromosome which disrupt dendrite morphology, flies carrying the GAL4 80 GFP chromosome were treated with the chemical mutagen ethyl methane sulfonateand 3,157 lethal mutant strains were established. Twenty-five of these displayed clear dendritic defects, falling into twelve complementation groups. Three of these complementation groups correspond to the previously identified genes flamingo, kakapo and enabled, and encode a seven-pass transmembrane protein, a large cytoskeletal protein and an Abl tyrosine kinase substrate, respectively. The remainder are potentially novel genes. Mutations in the genes sequoia and flamingo caused excessive dorsal branch outgrowth; mutations in tumbleweed, 
shrinking violet, kakapo, limber, ponderosa and saguaro caused branching defects; and mutations in enabled, yew and cypress caused misrouting. Mutation of the shrub gene led to weak elaboration of dendrites.

\section{Links}

For an online database of Drosophila genes and related information see FlyBase. The interactive fly has further information on genes involved in neural development, as well as many other processes.

\section{Reporter's comments}

This paper takes a major step forward in the systematic molecular analysis of dendrite development. An obvious limitation is that the function of nine of the genes identified remains unknown, but with the rapid advances in our knowledge of the Drosophila genome, this should be only a temporary problem. Only the second chromosome was screened in this study, but it ought to be possible to design similar screens for the third and $\mathrm{X}$ chromosomes and ultimately to build up a picture of the genetic interactions that occur during dendrite morphogenesis.

\section{Table of links}

Genes and Development

FlyBase

The interactive fly

\section{References}

1. Gao F-B, Brenman JE, Jan LY, Jan YN: Genes regulating dendritic outgrowth, branching, and routing in Drosophila. Genes Dev. 1999, 13: 2549-2561. 0890-9369 